\title{
Review of Quality Protein Maize as Food and Feed: In Alleviating Protein Deficiency in Developing Countries
}

\author{
Tekeba Eshetie* \\ Ethiopia Meat and Dairy Industry Development Institute, Debre Zeit, Ethiopia \\ *Corresponding author: tekebanega@gmail.com
}

\begin{abstract}
Maize is the major food and feed source in most parts of the world. In Ethiopia, it ranks second in area coverage after Teff and first in production. But maize alike other cereals, is deficient in certain essential amino acids like lysine and tryptophan. Therefore, this study is initiated to review the pros and cons of other maize variety called Quality Protein Maize as food, feed and other industrial uses and to suggest recommendations based on the findings. For the purpose, a number of national and international research findings were collected and used. The major lessons from this study indicated that, Quality Protein Maize has got a similar yield potential and disease resistance with normal maize and its biological value is about $80 \%$ whereas normal maize has got $40-75 \%$. It has also $90 \%$ the biological value of cow's milk with a true digestibility level of $60 \%$ which is greater than normal maize. The amino acid profile specially lysine and tryptophan is 2-3 fold higher than normal maize. Feeding of Quality Protein Maize to children in a number of countries indicated that the anthropometric measures are higher for the children fed with Quality Protein Maize than normal maize fed groups and also increased the intelligent quotient. Feeding of Quality Protein Maize to pregnant women showed a significant impact upon the health of the babies and mothers. The impact of Quality Protein Maize feeding to old age people reflected in their relief from gastric and other indigestion ailments. Feeding values of Quality Protein Maize to broiler chicks enhanced growth rate and meat quality. When broiler chicks fed with the combination of Quality Protein Maize and sesame seed meal, it can safely replace synthetic amino acids with better economic advantage than feeding with synthetic amino acids. In the case of layers, feeding of Quality Protein Maize improved age at first egg laying, egg production, and egg quality parameters. The major problems associated to the scaling ups of Quality Protein Maize include limited promotion, insufficient demonstration and poor awareness creation on its quality. On top of these, literally there is no premium price for the production of Quality Protein Maize and there is no special incentives for those producers. Therefore, research results should be properly documented and shared with the respective stakeholders, continuous awareness creation, demonstration and extension activities to producers and consumers should be done so as to use the potential in a proper manner. For effective promotion, back ward linkages and contract farming is also important to ensure sustainable supply of seed. It is also equally important to involve private players for seed production and link them with industries and encourage farmers to use yellow quality protein maize variety to increase the beta carotene contents of the diets.
\end{abstract}

Keywords: essential amino acids, lysine, mal-nutrition, normal maize, quality protein maize, tryptophan

Cite This Article: Tekeba Eshetie, "Review of Quality Protein Maize as Food and Feed: In Alleviating Protein Deficiency in Developing Countries." American Journal of Food and Nutrition, vol. 5, no. 3 (2017): 99-105. doi: 10.12691/ajfn-5-3-4.

\section{Introduction}

Maize has emerged as one of the most important crops as food, feed and industrial applications $[1,2,3]$ in most parts of the world. Maize alone contributes over $20 \%$ of the total calories in human diets in 21 countries, and over $30 \%$ in 12 countries that are home to a total of more than 310 million people $[2,3,4,5]$. Globally, maize is cultivated in 184 million hectares with the global production of 1,016 million tons $[6,7]$.

On the contrary, maize, alike other cereals, is deficient in certain essential amino acids, such as lysine and tryptophan $[1,7,8,9]$. According to [10], Lysine is critical in protein synthesis for the growth of tissues and found to be important in the absorption of calcium from the intestinal mucosa. On the other hand, Tryptophan being an essential amino acid is the biological precursor of the Bvitamin, niacin. Generally, efforts to improve protein quality in maize began in mid-1960s with the discovery of mutants (opaque 2 genes) that produce enhanced levels of lysine and tryptophan $[1,4,5,11,12]$. Finally, this mutant genes through conventional breeding work by scientists from International Maize and Wheat Improvement Centre (CIMMYT) developed a derivative of opaque-2 maize called Quality Protein Maize (QPM) which has hard endosperm, maize variety with similar yield to normal maize and nutritionally enhanced $[13,14,15]$. Therefore, this study is initiated to review national and international 
research outputs and come up with some sort of conclusions and recommendations to exploit the potential of quality protein maize as food, feed and industrial raw materials mainly by Ethiopian and other developing countries farmers whose livelihood is dependent largely on maize and feed processors with the following specific objectives.

\section{Objectives}

1. Review the food and feed values of QPM for human and animals and based on that to give recommendations

2. To explore the pros and cones of QPM and to suggest strategic interventions areas for its potential use specially in areas where maize is the dominant food and feed sources

\section{Origin and Production Potential of QPM}

Efforts to improve protein quality in maize began in mid-1960s with the discovery of mutants that produce enhanced levels of lysine and tryptophan, the two amino acids deficient in maize $[1,4,5,11,12]$. A natural spontaneous maize mutant with soft and opaque grain was found in maize field in USA during the 1920 's, which was later named as opaque 2 maize [16]. However, the soft endosperm of this opaque 2 maize variety was susceptible to insect pests and fungal diseases and reduced grain yield at its initial stage which gave the scientists further research assignments $[5,16]$. In line with this, some researchers in CIMMYT, found modifier genes that restored the desirable hard endosperm in materials containing the recessive Opeque-2 which are agronomically acceptable, tastes like normal maize, yields as much or more of normal maize, and nutritionally enhanced materials later came to be known as QPM $[13,14,15]$.

Quality Protein Maize was developed using conventional breeding techniques and contains nearly twice the amount of lysine and tryptophan as well as protein bioavailability that rivals milk casein and much usable protein as other maize grown in the tropics and yields $10 \%$ more grain than the traditional varieties of maize $[12,15,17]$. On the contrary, [5] reported a much lower grain yield of different QPM genotypes than the local check which may be due to external pressures like different agro-ecologies, variety difference, weather situation and other unforeseen factors. Others like $[12,18,19,20]$ reported that, the average grain yield of QPM ranges between 4-5 tons/ha which is equivalent to normal maize in most parts of the world but sometimes when sufficient Nitrogen level is applied to the soil, it goes up to 5.35 ton/ha [21] in Ethiopia.

In Sub-Saharan Africa, commercial QPM seed is currently available in 17 countries including Ethiopia and based on average 2003-2005 seed production data, approximately 200,000 hectares of land are being planted to different QPM cultivars of which 7,283 ha is found in Ethiopia [22].

\section{Nutritional Composition of QPM}

The biological value (amount of Nitrogen that is retained in the body) of QPM is about $80 \%$ whereas that of normal maize is $40-57 \%$ [23]. It is also mentioned that QPM has about $90 \%$ the biological value of cow's milk [24]. The study made by [25] indicated that QPM-based diets had a better biological value $(>60 \%)$ and true digestibility $(>60 \%)$ than the products from the normal maize. The study made by [26] indicated that on average, endosperm tryptophan is $45 \%$ higher and lysine $27 \%$ higher in QPM cultivars than in non-QPM cultivars.

According to [3], QPM, by virtue of its 2-3 fold higher lysine and tryptophan, and due to its higher biological value, balanced nitrogen index and leucine-isoleucine ratio, offers significant nutritional benefits, which is well demonstrated world-wide, both in terms of human food and animal feed. Despite the well- established nutritional benefits and varietal releases worldwide, cultivation and use of QPM as food and feed remains a major challenge. Of the 90 million ha of maize grown in Mexico, Central America, Sub-Saharan Africa and Asia, only $1 \%$ or less is covered by QPM [3]. Therefore, to alleviate these problems, the Government of Ethiopia has set a target to have QPM varieties cultivated on $20 \%$ of the country's total maize area in the coming few years including GTP II [27]. In terms of the quantity of energy and protein it contains, QPM has no difference with the normal maize as indicated in Table 1 and Table 2 but the difference lies in protein quality because it contains double the amount of Lysine and Tryptophan compared to normal maize $[1,2,28,29]$ and is essentially interchangeable with normal maize in cultivation and kernel phenotype [17].

Table 1. Nutritional Composition of QPM and Normal Maize Varieties

\begin{tabular}{|c|c|c|c|c|c|}
\hline \multirow{2}{*}{ Feed type } & \multicolumn{4}{|c|}{ Chemical Composition of QPM and Normal } & \multirow{2}{*}{ Reference } \\
\cline { 2 - 5 } & CP \% & EE \% & CF \% & ASH \% & \\
\hline QPM & 10 & 5.63 & 1.3 & 1.86 & {$[7]$} \\
\hline NM & 8.90 & 5.42 & 1.6 & 1.81 & {$[7]$} \\
\hline QPM & 9.73 & 5.1 & 5.03 & 1.46 & {$[30]$} \\
\hline NM & 9.94 & 3.27 & 4.52 & 1.20 & {$[30]$} \\
\hline QPM & 9.11 & 5.12 & 2.14 & 1.60 & {$[31]$} \\
\hline NM & 8.92 & 4.48 & 1.93 & 1.90 & {$[31]$} \\
\hline QPM & 9.00 & 5.12 & 6.26 & 2.38 & {$[32]$} \\
\hline NM & 9.00 & 4.48 & 2.34 & 2.03 & {$[32]$} \\
\hline
\end{tabular}

Note: $\mathrm{QPM}=$ Quality Protein Maize; $\mathrm{NM}=$ Normal Maize; $\mathrm{CP}=$ crude Protein; $\mathrm{EE}=$ Ether Extract; $\mathrm{CF}=$ Crude Fiber.

The results in Table 1 indicated that the crude protein content of QPM has no significant difference from normal maize. Similarly, the Ether Extract and Crude Fiber contents of QPM in most cases even higher than normal maize but as most studies indicated due to its higher amino acids profile (Table 2), bioavailability and biological values, QPM better supports the performance of both human and animals than normal maize. 
Table 2. The Amino acid Profiles of QPM and NM

\begin{tabular}{|c|c|c|c|c|c|c|c|c|c|c|}
\hline \multirow{2}{*}{ Feed source } & \multicolumn{9}{|c|}{ Amino acid Profiles of QPM and NM on DM bases (\%) } & \multirow{2}{*}{ Reference } \\
\cline { 2 - 12 } & Threonine & Tryptophan & Leucine & Valine & Methionine & Isoleucine & Cysteine & Lysine & Argnine & \\
\hline QPM & 0.27 & 0.07 & 0.82 & 0.43 & 0.16 & 0.27 & 0.22 & 0.28 & 0.44 & {$[31]$} \\
\hline NM & 0.22 & 0.05 & 1.04 & 0.40 & 0.17 & 0.30 & 0.17 & 0.21 & 0.35 & {$[31]$} \\
\hline QPM & 0.36 & 0.08 & 0.87 & 0.51 & 0.18 & 0.30 & 0.27 & 0.36 & 0.63 & {$[33]$} \\
\hline NM & 0.29 & 0.06 & 1.06 & 0.37 & 0.17 & 0.28 & 0.18 & 0.25 & 0.39 & {$[33]$} \\
\hline QPM & 0.45 & 0.10 & 0.96 & 0.57 & 0.21 & 0.36 & - & 0.43 & 0.75 & {$[34]$} \\
\hline NM & 0.38 & 0.06 & 1.34 & 0.50 & 0.22 & 0.36 & - & 0.27 & 0.42 & {$[3]$} \\
\hline QPM & 0.34 & 0.10 & 0.88 & 0.48 & 0.15 & 0.30 & 0.26 & 0.36 & 0.56 & {$[34]$} \\
\hline NM & 0.24 & 0.06 & 0.77 & 0.33 & 0.17 & 0.23 & 0.19 & 0.23 & 0.35 & {$[35]$} \\
\hline
\end{tabular}

Note: $\mathrm{QPM}=$ Quality Protein Maize; $\mathrm{NM}=$ Normal Maize; $\mathrm{DM}=$ Dry Matter.

\section{Feeding Values of QPM to Human}

Growth faltering is widespread among Ethiopian children, and the annual cost of under-nutrition to the country has been estimated at US $\$ 4.7$ billion, which amounts to $16.5 \%$ of the Gross Domestic Product (GDP), [36]. Among children under 5 years, $40 \%$ are stunted, $9 \%$ have acute malnutrition, and $25 \%$ are underweight [37]. On the other hand, the Government of Ethiopia has committed to significantly reduce child stunting by 2020 in its Second Growth and Transformation Plan (GTP II) and to eradicate child malnutrition by 2030 in its Seqota Declaration [38,39]. Dietary quantity and quality are poor among infants and young children in Ethiopia, with less than half (49\%) of all children aged 6-23 months receiving the minimum recommended number of meals and only $5 \%$ consuming a sufficiently diversified diet [40].

The feeding trial on children for 6 months at Rajendra Agricultural University, Pusa Bihar in India on the efficiency of QPM over normal maize grains revealed that the anthropometric measurements i.e. body weight and arm circumference of children fed with QPM were remarkably higher compared to children fed with normal maize grain [41]. Other study done by [15] indicated that when QPM replaced Normal Maize in human nutrition specially the adult feeding, a reduction by $40 \%$ in maize intake relative to common maize to meet the protein requirements was observed which has got also a direct cost implications for the people which depend mainly on maize based diets (Figure 1). Estimated target QPM intake levels of $100 \mathrm{~g} / \mathrm{d}$ for young children and $500 \mathrm{~g} / \mathrm{d}$ for adults were calculated to meet $100 \% \mathrm{WHO}$ and IOM protein, lysine and Tryptophan requirements [15]. This report further indicated that switching from common maize to QPM provides a more balanced protein source relative to common maize without scarifying energy, yield, micro-nutrients or changing native food supply systems.

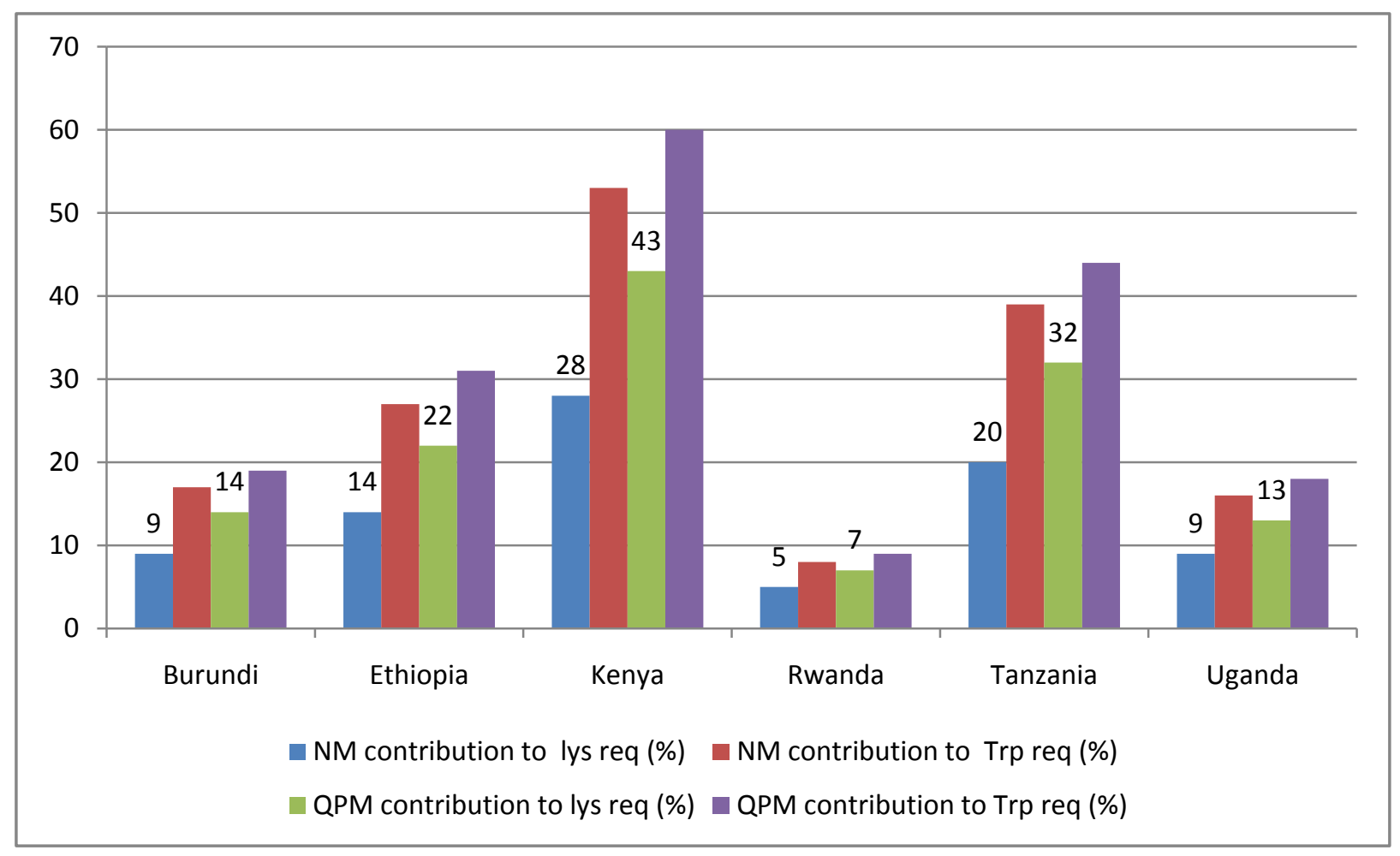

Figure 1. The contribution to Lysine and Tryptophan when QPM replaced Normal Maize in adult feeding for some East African countries (Source: Calculated by the author from [15]) 
According to [2], QPM can contribute to reducing protein deficiency particularly in young children. The study further indicated that in Colombia and Peru, malnourished children were restored to health on controlled diets using QPM. In Ghana the introduction of QPM into village plagued with severe child malnutrition resulted in healthier children and economic gains. A QPM feeding experiment conducted in India using young children of age 1-3 years for 180 days indicated that, the QPM fed groups performed best in weight, height, head circumference, chest circumference and arm circumference parameters as compared to normal maize, control plus milk fed and control diets [42]. Based on their findings, they concluded that substitution of conventional maize with QPM is the good option for combating protein malnutrition and poor growth, particularly among young children of low socio-economic groups subsisting on maize. The study presented by [22] indicated that lysine and tryptophan contribution as percent of protein requirement indicated that, QPM can satisfy 69 and 73\% of the requirements, respectively which are double the contribution of normal maize on the children between the age of 2-5 as indicated in Figure 2.

A number of different studies made in a number of countries across the world indicated that, young children recovering from malnutrition were fed with QPM based diets as their only source of protein indicated the superiority of QPM based diets over regular maize with respect to indicators such as apparent nitrogen retention and biological value [22]. The result further indicated that, recovering mal-nouritioned children fed QPM showed the same growth as those fed with modified cow milk formula. The body weight gain of QPM fed groups were even better than those fed with control group supplemented with milk which may be due to the nutritional level of the control diet and the amount of milk used as a supplement. On the other hand the higher level of lysine, tryptophan and the balanced leucine-isoleucine ratio in QPM based diet may resulted a better body weight gain of children as compared the other groups as it is seen in Figure 3.

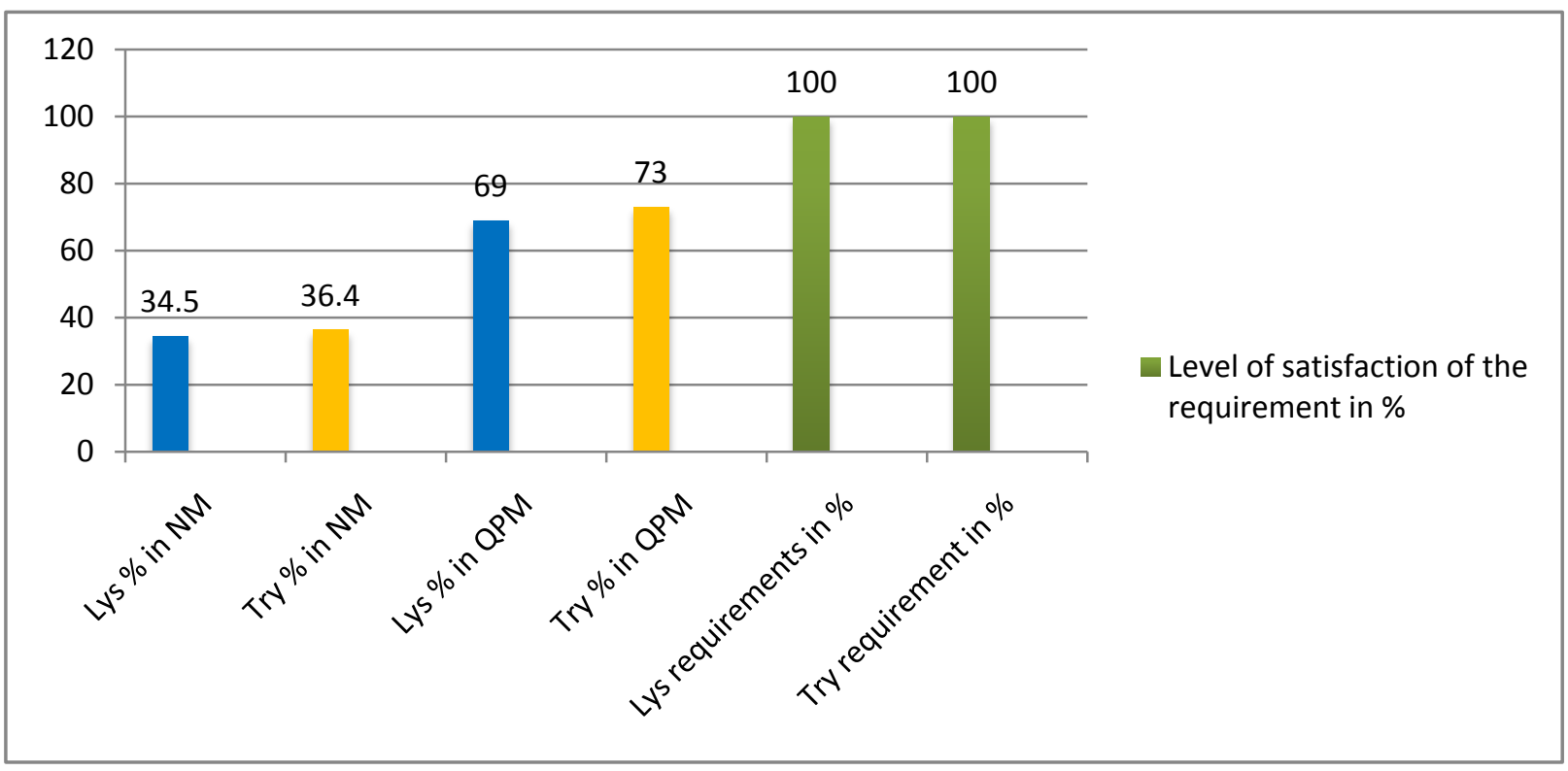

Figure 2. Lysine and Tryptophan contribution from QPM and Normal Maize using FAO guideline requirements for 2-5 years children (Source: calculated by the author from [22])

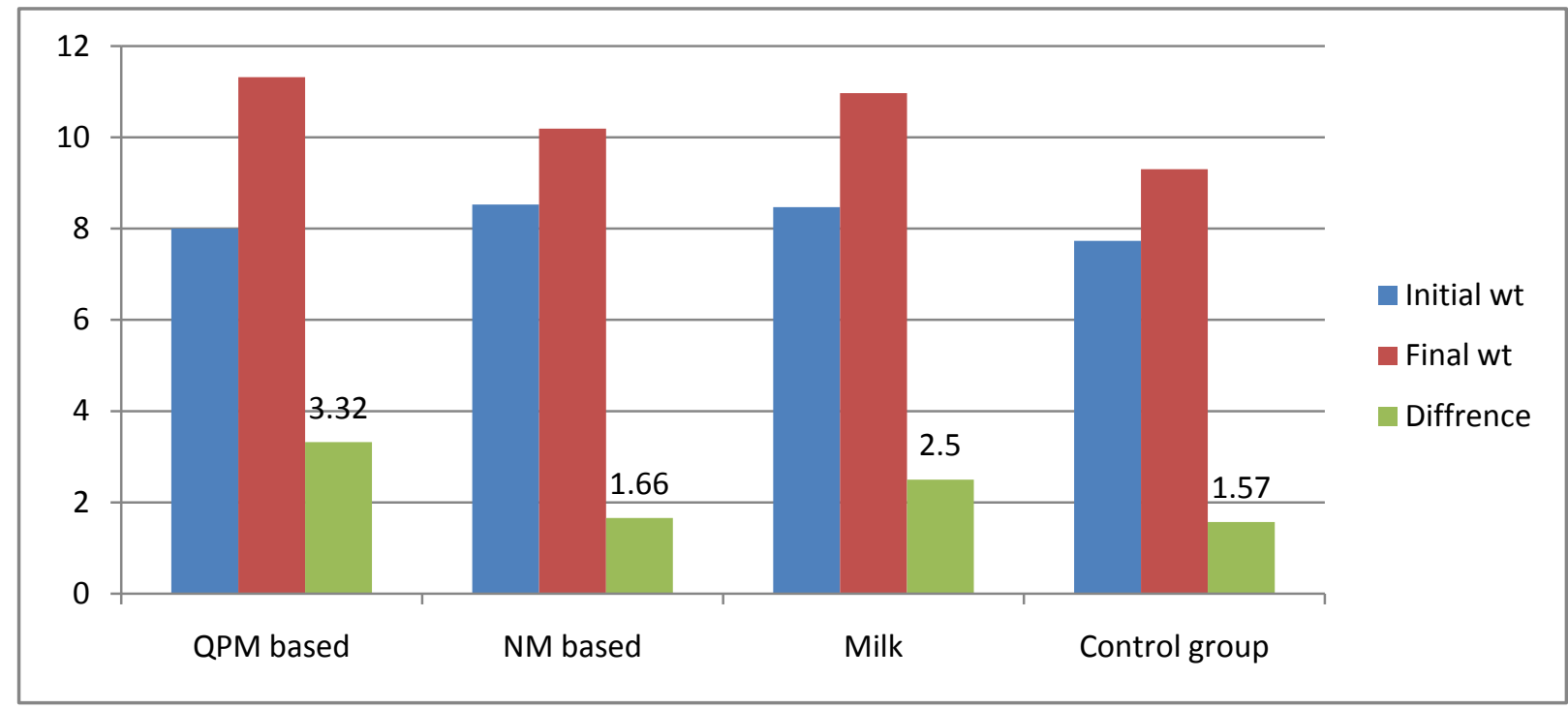

Figure 3. Mean initial and final body measurements of children fed with QPM based and other diets (Source: [42]) 


\section{Feeding Values of QPM and Normal Maize on Poultry and Other Animal Species}

A feeding trial conducted in China using laying hens by [43], indicated that simply replacing normal maize with QPM resulted in enhanced egg production and the feed intake highly improved for laying birds fed with QPM based diet as compared to normal maize fed groups. This feeding trial also indicated that yolk pigmentation improved as a result of QPM in the diet. But similar study made by [44], indicated that, eggs from layers fed diet with QPM-based diet had lower yolk colour score than those laying birds fed with normal maize-based diet, may be due to inclusion of white variety QPM in the diet. But the mean feed conversion ratio tended to be lower in layers fed with QPM-based diet than those fed with normal maize-based diet. [44] also reported that, income over feed cost was higher by $4.85 \%$ for QPM-based diet than for NM-based diet, which was associated with the additive effect of higher sale value and lower cost of feed of the former than the later. However, dietary treatment has no noticeable effects on egg weight, FCR, soft and broken egg percentage or Haugh unit in the same study. On the other hand, the research done by [31] indicated that, addition of QPM to layers diets had significant effects on the age at first egg, at the age when $50 \%$ egg production achieved on daily hen housed egg production. This implies, QPM can be used in layer chicken diets to cut down the cost of using fish meal and results in considerable financial benefits without scarifying performance.

[31] also found that, when layers pullets were fed with QPM based diet, protein levels reduced to $14 \%$ without any adverse effects on their performance. On the other hand, a study done using white rats in the laboratory by [25] indicated that QPM based diet fed group was 41\% higher than normal maize fed group in their protein efficiency ratio (2.08 vs 1.48). Inclusion of QPM in poultry ration enabled the feed manufacturer to produce feeds requiring minimal or' no additional supplementation of crystalline amino acids particularly lysine and tryptophan as a result it holds immense contribution to the overall profitability of poultry business [3,29].

Two experiments conducted by [35] on broiler starter chicks using QPM and NM as sole source of protein and amino acids after being balanced for vitamins and minerals by the addition of a vitamin-mineral pre-mix. In the second stage of the experiment, broiler chicks were fed with combined starter-finisher diets of varying protein contents in which QPM replaced NM. The aim of the later experiment was to assess the potential for reducing dietary fishmeal incorporation as QPM replacing NM. In the first experiment birds receiving QPM as the sole source of amino acids performed significantly better than their counter parts fed with NM. In addition broilers in similar experiment which were fed with QPM weighed an average $708 \mathrm{~g}$ each at the end of the trials compared with $532 \mathrm{~g}$ for those fed on NM. The corresponding FCF were 4.28 and 6.55 , respectively. In the finisher experiment, the use of QPM allowed the fishmeal to be reduced from 19.5 to $13.5 \%$ without adversely affecting performance which implied broiler production using QPM based diet is more cheaper than NM based diet. Similar experiment done on broiler chicks by [10] indicated that as the level of QPM inclusion increased from 0 to $100 \%$ against normal maize, the feed/gain ratio increased from 3.62 to 2.12 , respectively (where 3.62 is referring when QPM was zero and 2.12 when $100 \%$ QPM included). A feeding trial done by [30] on broiler chicks using QPM combined with sesame seed meal as a replacement for synthetic amino acids indicated that, when $30-36 \%$ QPM combined with $15-17.3 \%$ sesame seed meal, it safely and economically be used to substitute synthetic amino acids in broiler chicks and finisher ration with better economic advantage than commercial ration with synthetic amino acids.

Another study which was conducted in Kenya using broiler chicks indicated that, a 5\% reduction in cost was observed when QPM was substituted for NM [45]. A feeding trial using weaner pigs by [12] indicated that, weaner pigs fed with QPM diet had the highest feed conversion efficiency and was cheaper than normal maize fed weaner pigs and was cheaper because less protein source was included in QPM based diets. A feeding trial done in China using QPM and NM based diets indicated that QPM can command 29.8\% more daily weight gain in pigs compared to NM [46]. But another study made by [32] indicated the absence of significance difference in growth performance of piglets fed with QPM and Normal Maize which may be due to the amount and quality of other feed ingredients incorporated in maize based diets.

[31] reported that QPM based diets in growing pullets (8-18 weeks) resulted in higher performance compared to NM feeds, and the crude protein levels in QPM diet could be reduced to $14 \%$ without any adverse effects on performance. [47] observed no significance difference on body weight gain in RIR starter chicks (0-8 weeks) fed diets containing either QPM or NM. But, Feed Conversion Efficiency was significantly improved for the group fed with QPM based diet. When QPM was included in the diet of grower chicks (9-16 weeks), significantly higher body weight gain and improved Feed Conversion Ratio was seen compared to those fed on the NM diet. On the contrary, the study made by [33] using (0-8 wks old) White Leghorn chicks did not show any significant effect on body weight gain with dietary replacement of NM by QPM this may be due to the genetic characteristics of White Leghorn chicks more towards egg laying traits than body weight development.

\section{Conclusion}

Normal maize is the dominant crop in most parts of the world as staple food for human and animal feed and also as industrial raw materials. But, when it comes to its nutritional content, alike most cereals it is deficient in essential amino acids like lysine and tryptophan. Therefore, as widely reported this limitation in maize insisted the researchers to developed a new maize variety with better nutritional profile and similar yield with normal maize. This new maize variety, Quality Protein Maize is superior to NM in its amino acids balance and nutrient composition, biological value which could improve the performance of both human and animals. It is also more economical to use diets incorporating QPM as it can lead to progressive reductions of other protein sources 
and synthetic amino acids addition. Most of the nutritional studies conducted to investigate the feeding value of QPM have shown beneficial effects on performance in human, broilers, layers and other animal species. In poultry diets based on QPM needed minimal or no synthetic lysine supplementation to elicit a similar performance as those birds fed nutritionally balanced NM based diets supplemented with synthetic lysine. However, the expansion and scaling ups of QPM as per the requirement and its quality benefit is very limited due to insufficient promotion, poor awareness creation on stakeholders and under developed market linkage and incentive mechanisms

\section{Recommendations}

- Continuous supply of QPM grains for the industry needs to be ensured through effective backward linkages and contract farming to ensure sustainable supply of QPM.

- Better demonstration, promotion and also awareness creation of stakeholders on QPM using proper channels to use it as food and feed.

- To harness full potential of QPM, there is an urgent need to sensitize the food processing and value addition industries in Ethiopia and other developing countries on nutritional benefits of QPM, so as to generate and deploy QPM-based value-added food products in both rural and urban markets.

- The potential of QPM, especially yellow QPM should be promoted so as to strengthening the maize-poultry value chain and to properly utilize the sector

- Further research on the cost-benefit ratio of QPM to determine the value gained in terms of $\mathrm{kg}$ of meat and number of eggs and also the quality of the products by using QPM over conventional maize is required at each production settings.

- Incentives should be available like premium price for the QPM producers and value addition over normal maize grains.

- It is equally important to involve private players for seed production and link the industry with the farmers, so that the latter get an assured premium for their QPM produce.

\section{References}

[1] Prasanna, B.M., Vasal, S.K., Kassahun, B. and Singh N.N. (2001) Quality Protein Maize Current Science, Vol. 81, No. 10. Division of Genetics, Indian Agricultural Research Institute, New Delhi, India.

[2] Marcos L.(2005). Combining ability for grain yield of Quality Protein Maize under low soil nitrogen. A dissertation submitted to the school of Agricultural Sciences of University of Zambia in partial fulfillment of the requirements of Master of Science in Agronomy.

[3] TAAS (Trust for Advancement of Agricultural Sciences) (2015). Up scaling Quality Protein Maize for Nutritional Security Indian Agricultural Research Institute, Pusa Campus, New Delhi-110 012, India.

[4] Sentayehu, A. (2008). Protein, Tryptophan and Lysine contents in Quality Protein Maize, North India. Ethiop J Health Sci. Vol. 18, No. 2.

[5] Aman, J., Bantte, K., Alamerew, S. and Tolera, B. (2016) Evaluation of Quality Protein Maize hybrids at Jimma, WesternEthiopia. Journal of Forensic Anthropology 1(1).
[6] Agrawal, P.K. and Gupta, H.S. (2010). Enhancement of protein quality maize using biotechnological options. Animal Nutrition and Feed Technology 10: 79-91.

[7] Wubu, T. Z. (2011). Effect of graded level of Quality Protein Maize and normal maize on egg production, egg quality and hatchability of white leghorn hens. MSc Thesis, submitted to the school of graduate studies, Haramaya University, Ethiopia.

[8] Lauderdale, J. (2000). Issues Regarding Targeting and Adoption of Quality Protein Maize (QPM). CIMMYT (International Maize and Wheat Improvement Center). Mexico D.F., 30p.

[9] Abate, T., Shiferaw, B., Menkir, A., Wegary, D., Kebede, Y., Tesfaye, K., Kassie, M., Bogale, G., Tadesse, B., and Keno, T. (2015). Factors that transformed maize productivity in Ethiopia. Food Security. 2015: 7(5): 965-981.

[10] Onimisi, P.A., Omage, J.J., Dafwng, I.I. and Bawa, G.S. (2009). Replacement value of Normal Maize with Quality Protein Maize in Broiler Diets. Pakistan Journal of Nutrition 8 (2): 112-115.

[11] FAO (United Nation Food and Agriculture Organization) (2002). Protein Sources for the Animal Feed Industry. Expert Consultation and workshop Bangkok, 29 April-3 May 2002.

[12] Mpofu, I.D.T., Sibanda, S., Shonihwa, A. and Pixley (2012). The Nutritional value of Quality Protein Maize for Weaner Pigs. J. Pet.Environ. Biotechnol, 3 (5).

[13] Bjamason, M. Vasal, SK. (1992). Breeding of Quality Protein Maize. Plant breeding review 9: 181-216.

[14] Hugo, C. and Mike, L. (2001). Quality Protein Maize: Improved Nutrition and Livelihoods for the poor. In: Sustainable Maize Production Systems for Nepal. Proceedings of Maize Symposium, Held December 3-5, 2001, Kathmandu, Nepal.

[15] Nuss, E.T. and Tanumihardjo, S.A. (2011). Quality Protein Maize for Africa: Closing the protein Inadequacy Gap in Vulnerable Populations. American Society for Nutrition. Adv.Nutr.2:217-224.

[16] Gupta, H.S., Agrawal, P.K., Mahajan, V., Bisht, G.S., Kumar, A., Verma, P., Srivastava, A., Saha, S., Babu, R., Pant, M.C. and Mani, V.P. (2009). Quality Protein Mazie for nutritional security: rapid development of short duration hybrids through molecular marker assisted breeding. Current Science, Vol. 96, No. 2.

[17] Vasal, S.K. (2000). Quality Protein Maize: overcoming the hurdles. Journal of crop production 6: 193-227.

[18] Jaliya, M.M., Falaki, A.M., Mahmud, M. \& Sani, Y.A. (2008) Effect of sowing date and NPK fertilizer rate on yield and yield components of Quality Protein Maize. ARPN Journal of Agricultural and Biological science. Vol. 3, No. 2.

[19] Bello, O.B., Ganiyu, O.T., Wahab, M.K.A., Azeez, M. A., Abdulmaliq, S.Y., Ige, S.A., Mahmood, J., Oluleye, F., and Afolabi, M.S. (2012). Yield and disease reactions of Quality Protein Maize Varieties in the Southern Guinea Savanna AgroEcology of Nigeria. International Journal of Agriculture and Forestry 2(5): 203-209.

[20] Abdurrahman, B.I. (2013). Yield stability and mega environment analysis based on the performance of Quality Protein Maize in Sub-Saharan Africa. Dissertation submitted to Department of Plant Sciences, Faculty of Natural and Agricultural Sciences, University of Free State, Bloemfontein, South Africa.

[21] Tadesse, A. and Hae koo Kim (2015). Yield related traits and yield of Quality Protein maize affected by nitrogen levels to achieve maximum yield in the central rift valley of Ethiopia. Journal of Biology, Agriculture and Healthcare Vol. 5 (15).

[22] Krivannek, A.F., Hugo De Groote, Gunaratna, N.S., Diallo, A.O. and Friesen, D. (2007). Breeding and disseminating Quality Protein Maize (QPM) for Africa. African Journal of Biotechnology Vol. 6 (4), pp. 312-324.

[23] Bressani, R (1992). Nutritional value of high lysine maize in humans. In Mertz E.T. (ed.) Quality Protein Maize. American Association of Cereal Chemists.

[24] NRC (National Research Council) (1988). Quality Protein Maize. National Academy Press. Washington D.C.

[25] Abiose, S.H., Ikujenlola, A.V., and Abioderin, F.I. (2015). Nutritional quality Assessment of Complementary Foods Produced from Fermented and Malted Quality Protein Maize Fortified with Soybean Flour. Pol. J. Food. Nutr. Sci. Vol.65, No.1, pp. $49-56$

[26] Mosisa, W., Marianne, B., Dnnis, F., Gunda, S.A.M., Alpha, O.D., Bindiganivile, V. \& Walter, J.H. (2007). Protein quantity and quality, and grain yield of Quality Protein Maize and normal endosperm Maize under different levels of Nitrogen. African crop Science Conference Proceedings Vol. 8 pp.1905-1909. 
[27] Tessema, M., Gunaratna, N.S., Donato, K., Cohen, J.L., McConnel, M., Belayneh, D., Brouwer, I.D., Belachew, T. and Hugo De Groote (2016). Translating the impact of Quality Protein Maize into improved nutritional status for Ethiopian children: study protocol for a randomized controlled trial. BMC Nutrition vol. 2(54).

[28] Panda, A.K., Raju, M.V.L.N., Rama Rao, S.V., Lavanya, G., Pradeep Kumar Reddy, E. and Shyam Sunder, G. (2010). Replacement of normal maize with Quality Protein Maize on performance, immune response and carcass characteristics of broiler chickens. Asia Australian Journal of Animal Sciences 23: 1626-1631.

[29] Panda, A.K., Prakash, B., Rama, S.V., RAO, Raju, M.V.L.N., and Shyam Sunder, G. (2013). Utilization of high Quality Protein Maize in poultry. World's Poultry Science Journal, Vol. 69.

[30] Tekeba E. Moudgal R. and Alemu Y. (2007). Compatibility of Quality Protein Maize and Sesame Seed Meal as a Substitute for Synthetic Amino Acids in Broiler Ration. The Icfai Journal of Life Sciences, India 1(2): 16-30.

[31] Osei, S. A., Dei, H.K., and Tuah, A. K. (1999). Evaluation of Quality Protein Maize as a feed ingredient for layer pullet. Journal of Animal and Feed Sciences 8: 181-189.

[32] Tiwari, M.R., Chapagain, B.P., Shah, M.K. and Shrestha, Y.K (2013). Evaluation of Quality Protein Maize for Growth performance of Crossbred Piglets in Western Hills of Nepal. Global Journal of Science Frontier Research Agriculture and Veterinary. Volume 13 (6).

[33] PANDA, A.K., RAJU, M.V.L.N., RAMARAO, S.V., LAVANYA, G., PRADEEP KUMARREDDY,E. and SHYA.1WSUNDER, G. (2011). Nutritional evaluation and utilisation of Quality Protein Maize, Nityashree hybrid maize and normal maize in broiler chicken. British Poultry Science 52: 632-638.

[34] Ortega, E.I.E., Villegas, E. and Vasal, S.K. (1986). A comparative study of protein changes in normal and Quality Protein Maize during tortilla making. Cereal Chemistry 63 (5): 446-451.

[35] Osei, S.A., Atuahene, C.C., Okai, D.B., Donkoh \& Tuah, A.K. (1998). The nutritive value of Quality Protein Maize in the diets of broiler chickens. Ghana Jnl Agric. Sci. 31, 1-5.
[36] UNECA (United Nation Economic Commission for Africa), (2014). The cost of hunger in Africa: Social and economic impact of child under nutrition in Egypt, Ethiopia, Swaziland and Uganda. World Food program, Addis Ababa, Ethiopia.

[37] CSA (Central Statistical Agency) (2014). Agricultural Sample Survey: report on areas and production of major crops. Statistical Bulletin, volume 1: Addis Ababa.

[38] National Planning Commission (2015). The Second Growth and Transformation Plan (GTP II) (2015/16-2019/20). Addis Ababa: The Federal Democratic Republic of Ethiopia.

[39] MoANR (Ministry of Agriculture and Natural Resources) (2016). Nutrition sensitive Agriculture Draft Strategic Plan Addis Ababa: Federal Democratic Republic of Ethiopia, 2016

[40] CSA (Central Statistical Agency) and ICF International (2012). Ethiopia Demographic and health survey 2011. Addis Ababa, Ethiopia, and Calverton, Maryland, USA.

[41] Mamatha, H., Meena, M. K. and Pushpa Chethan Kumar (2017). Quality Protein Maize as Balanced Nutrition for Human Diets. Advances in Plants \& Agriculture Research, Vol. 6 (2).

[42] Chopra, N., Bhargawa, A. and Kumar, A. (2011). Effect of feeding quality protein maize on growth of young children. Food Science Research journal; Volume 2 issue 2. pp: 173-178.

[43] Zhai, Shao-Wei. (2002). Nutritional evaluation and utilization of quality protein maize in laying hen feed. MSc Thesis, Shaanxi 712100, P.R. China.

[44] Joice, V., San Andres, Neil Alvin, A., Soriano, Alona, T., Badua and Ernesto A. Martin (2011). Quality Protein Maize in Least-cost diet for laying hens. Department of Animal Science, Central Luzon State University, Muzon, Nueva Ecija, Philippines.

[45] Nyanamba, T., De Groote, H. and Wahome, R. (2003). Quality Protein Maize for the feed industry in Kenya. Poster paper presented at the international Agricultural economics Associations, Durban, South Africa, August, 2003.

[46] De-Quan, S., Shi-Huang, Z. (1994). Maize production and QPM breeding program in China. International symposium on QPM. December 1-3 Sete Lagoas, MG Brazil, pp 238-239.

[47] Eshetie, T. Moges, F. and Zeleke, G. (2011). Effect of Quality Protein Maize on growth and body weight gain performance of RIR breed of chickens. The IUP Journal of Life Sciences 4: 46-53. 